\title{
Microbial characterization of a subzero, hypersaline methane seep in the Canadian High Arctic
}

\author{
Thomas D Niederberger ${ }^{1}$, Nancy N Perreault ${ }^{1,2}$, Stephanie Tille ${ }^{3}$, Barbara Sherwood Lollar ${ }^{3}$, \\ Georges Lacrampe-Couloume ${ }^{3}$, Dale Andersen ${ }^{4}$, Charles W Greer ${ }^{2}$, Wayne Pollard ${ }^{5}$, \\ Lyle G Whyte ${ }^{1}$ \\ ${ }^{1}$ Department of Natural Resource Sciences, McGill University, Ste-Anne-de-Bellevue, Quebec, Canada; \\ ${ }^{2}$ Biotechnology Research Institute, National Research Council of Canada, Montreal, Quebec, Canada; ${ }^{3}$ Stable \\ Isotope Laboratory, University of Toronto, Toronto, Ontario, Canada; ${ }^{4}$ SETI Institute, Mountain View, CA, \\ USA and ${ }^{5}$ Department of Geography, McGill University, Montreal, Quebec, Canada
}

\begin{abstract}
We report the first microbiological characterization of a terrestrial methane seep in a cryoenvironment in the form of an Arctic hypersaline ( $\sim 24 \%$ salinity), subzero $\left(-5^{\circ} \mathrm{C}\right)$, perennial spring, arising through thick permafrost in an area with an average annual air temperature of $-15{ }^{\circ} \mathrm{C}$. Bacterial and archaeal 16S rRNA gene clone libraries indicated a relatively low diversity of phylotypes within the spring sediment (Shannon index values of 1.65 and 1.39, respectively). Bacterial phylotypes were related to microorganisms such as Loktanella, Gillisia, Halomonas and Marinobacter spp. previously recovered from cold, saline habitats. A proportion of the bacterial phylotypes were cultured, including Marinobacter and Halomonas, with all isolates capable of growth at the in situ temperature $\left(-5^{\circ} \mathrm{C}\right)$. Archaeal phylotypes were related to signatures from hypersaline deep-sea methane-seep sediments and were dominated by the anaerobic methane group 1a (ANME-1a) clade of anaerobic methane oxidizing archaea. CARD-FISH analyses indicated that cells within the spring sediment consisted of $\sim 84.0 \%$ bacterial and $3.8 \%$ archaeal cells with ANME-1 cells accounting for most of the archaeal cells. The major gas discharging from the spring was methane $(\sim 50 \%)$ with the low $\mathrm{CH}_{4} / \mathrm{C}_{2}$ ratio and hydrogen and carbon isotope signatures consistent with a thermogenic origin of the methane. Overall, this hypersaline, subzero environment supports a viable microbial community capable of activity at in situ temperature and where methane may behave as an energy and carbon source for sustaining anaerobic oxidation of methane-based microbial metabolism. This site also provides a model of how a methane seep can form in a cryoenvironment as well as a mechanism for the hypothesized Martian methane plumes.
\end{abstract}

The ISME Journal (2010) 4, 1326-1339; doi:10.1038/ismej.2010.57; published online 6 May 2010

Subject Category: microbial ecology and functional diversity of natural habitats

Keywords: cryo-environment; Arctic spring; methane seep; microbial ecology

\section{Introduction}

Cold saline groundwater springs discharge at several locations on Axel Heiberg Island (AHI) in the Canadian High Arctic and are linked to subpermafrost groundwater flow through carboniferous evaporites in areas of diapiric uplift (Pollard et al., 1999; Andersen et al., 2002). These springs are among the only known cold springs in thick permafrost on Earth (Andersen et al., 2002) and the geomorphology, chemistry, thermal environment and microbiology of two sets of moderately cold, saline springs (Gypsum Hill (GH), Colour Peak (CP))

Correspondence: LG Whyte, Department of Natural Resource Sciences, McGill University, 21,111 Lakeshore Road, Ste-Annede-Bellevue, Quebec H9X 3V9, Canada.

E-mail: lyle.whyte@mcgill.ca

Received 23 November 2009; revised 16 March 2010; accepted 24 March 2010; published online 6 May 2010 located at Expedition Fiord on AHI have been extensively studied (Pollard et al., 1999; Andersen et al., 2002; Perreault et al., 2007, 2008; Niederberger et al., 2009). These springs flow throughout the entire year with constant discharge temperatures ranging from -0.5 to $6.9^{\circ} \mathrm{C}$, and discharge waters that are moderately saline $(7.5-15.8 \%$ salts $)$, anoxic (mean oxido-reduction potential (ORP) of $-325 \mathrm{mV}$ ), near-neutral ( $\mathrm{pH}$ 6.9-7.5), rich in both sulfate (2300$3724 \mathrm{mgl}^{-1}$ ) and sulfide (25-100 p.p.m.) (Andersen et al., 2002; Perreault et al., 2007).

An initial microbiological survey by Perreault et al. (2007) revealed that the majority of the $16 \mathrm{~S}$ rRNA gene phylotypes detected within the sediment at the source of the springs were related to microorganisms involved in sulfur cycling with the major metabolic processes appearing to be the oxidation of reduced sulfur compounds. Further work identified culturable microbes from the spring sediments with autotrophic and sulfur-oxidation 
activities (Perreault et al., 2008), and the small amounts of hydrocarbons in gases exsolving from these springs were compositionally and isotopically consistent with microbial methanogenesis and possible methanotrophy (Perreault et al., 2007). Niederberger et al. (2009) characterized gray-colored microbial streamers that form during the winter months in the snow-covered regions of the GH spring runoff channels. Culture, molecular and microscopicbased analysis of the 16S rRNA gene indicated that the streamers were dominated by chemolithoautotrophic sulfur-oxidizing Thiomicrospira species that oxidized both sulfide and thiosulfate and fixed $\mathrm{CO}_{2}$ under in situ conditions (Niederberger et al., 2009). These collective studies indicate that the utilization and cycling of sulfur compounds may have a major role in the energy production and maintenance of microbial communities in the GH and $\mathrm{CP}$ spring environments (Perreault et al., 2007; Niederberger et al., 2009). These cold saline springs are regarded as analogues to possible Martian liquid water habitats (Andersen et al., 2002). For example, Mars Global Surveyor images recently detected new gully deposits, formed since 1999, providing exciting and compelling evidence that liquid water (possibly brines from the Martian subsurface) flowed on Mars during the past decade, under mean surface temperatures of $-60^{\circ} \mathrm{C}$ and extensive permafrost (Malin et al., 2006); evidence of other spring-like structures on Mars has also been recently reported (Allen and Oehler, 2008; Rossi et al., 2008).

In 2004, a new spring was located on west central AHI called Lost Hammer (LH) spring, which differs from the other springs on the Island in several ways. It consists of a subzero $\left(-5^{\circ} \mathrm{C}\right)$ relatively hypersaline $(24 \%)$ discharge situated in the middle of the valley floor unrelated to any other surface structure or topography and is characterized by a hollow coneshaped salt tufa structure. There is a continuous flow of gas exsolving from the center of the spring with the major gas emitted being methane. Sites characterized by high methane discharges and high salinities in cold temperature environments such as LH have not previously been described in terrestrial settings. Globally, such seeps are located at deep-sea marine sediments where methane hydrates, mud volcanoes and brine pools occur (Valentine and Reeburgh, 2000; Valentine, 2002; Zhang et al., 2003; Joye et al., 2004; Orcutt et al., 2005). In this respect, LH also represents an important Mars analogue as to how a methane seep can exist within thick permafrost and provide a possible mechanism to the reported methane plumes on Mars. It was recently postulated by Mumma et al. (2009) that the 10 p.p.b. methane reported in the Mars atmosphere (Formisano et al., 2004) may originate from localized 'hot spots' or 'plumes' of methane arising from the frozen terrestrial Martian surface. The origin of these plumes is under extensive debate (Lefèvre and Forget, 2009) and could be attributable to either geological or biological sources, the latter including methanogenesis by microbial communities inhabiting the Martian subsurface. For example, terrestrial methanogens and associated evidence of in situ methanogenic activity have been detected in similar Earth analogue cryo-environments such as Greenland deep subsurface glacial ice cores (Tung et al., 2005; Rohde et al., 2008) and permafrost (Rivkina et al., 2007). Laboratory microcosm analyses also indicate biological methane formation can occur at subzero temperatures in permafrost (Rivkina et al., 2007). Hypersaline surface environments associated with flowing water may also have recently existed on Mars (McLennan et al., 2005; Osterloo et al., 2008) and methanogenesis is known to occur in terrestrial hypersaline environments (Oremland et al., 1982; Conrad et al., 1995; Bebout et al., 2004; Potter et al., 2009), although these studies have been limited to unfrozen, temperate hypersaline sites.

Here we report the first microbiological and geochemical characterization of the only known terrestrial methane seep in a cryo-environment on Earth in the form of the hypersaline subzero spring, which arises through thick extensive permafrost in an area with an average annual air temperature of $-15{ }^{\circ} \mathrm{C}$ and with air temperatures below $-40{ }^{\circ} \mathrm{C}$ common during the winter months. This site provides a model of how a methane seep can form in a hypersaline cryo-environment and can support a viable microbial community where the methane itself may behave as an energy and carbon source for sustaining anaerobic oxidation of methane.

\section{Materials and methods}

Sample collection and geochemical analyses

Sediment and spring samples for geochemical, DNA, microscopic and culturing analyses were collected aseptically into sterile polypropylene tubes (Fisher, Ottawa, ON, Canada) by an ethanol sterilized metal spatula and a sterile $60 \mathrm{ml}$ syringe, respectively. Samples were subsequently kept frozen $\left(<-5{ }^{\circ} \mathrm{C}\right)$ during transport to the laboratory. Multiple geochemical parameters including temperature, $\mathrm{pH}$, dissolved oxygen, conductivity, salinity, total dissolved solids and ORP were measured using the YSI 556 Multi Probe System (YSI Incorporated, Yellow Springs, OH, USA). Hydrogen sulfide and dissolved oxygen concentrations were also measured by colorimetric assay, as per manufacturer's instructions (CHEMetrics, Calverton, VA, USA) (Perreault et al., 2007). The major cations, anions and carbon content of LH sediment and spring water were determined by Maxxam Analytique Inc. (Lachine, Quebec, Canada).

Gas analyses

Gas samples were collected as in the work of Ward et al. (2004) and Perreault et al. (2008). 
Compositional analyses of gas phase samples were performed on a Varian (Palo Alto, CA, USA) 3400 gas chromatograph (GC) equipped with a flame ionization detector to determine concentrations of $\mathrm{CH}_{4}, \mathrm{C}_{2} \mathrm{H}_{6}, \mathrm{C}_{3} \mathrm{H}_{8}$ and $\mathrm{C}_{4} \mathrm{H}_{10}$. The hydrocarbons were separated on a J\&W Scientific GS-Q column $(30 \mathrm{~m} \times 0.32 \mathrm{~mm}$ i.d.) with a helium gas flow and the following temperature program: initial temperature of $60{ }^{\circ} \mathrm{C}$, hold for $2.5 \mathrm{~min}$, increased to $120^{\circ} \mathrm{C}$ at $5{ }^{\circ} \mathrm{C} \mathrm{min}^{-1}$. Both an HP 5830A and a Varian 3800 GC equipped with a micro-thermal conductivity detector and Molecular Sieve 5A PLOT columns $(25 \mathrm{~m} \times 0.53 \mathrm{~mm}$ i.d.) were used to determine concentrations of the inorganic gas components $\left(\mathrm{H}_{2}, \mathrm{He}\right.$, $\mathrm{O}_{2}, \mathrm{CO}_{2}$ and $\mathrm{N}_{2}$ ). To determine concentrations of $\mathrm{H}_{2}$, the argon carrier gas flow rate was $2 \mathrm{ml} \mathrm{min}^{-1}$ and the temperature program was: initial temperature of $10^{\circ} \mathrm{C}$, hold for $10 \mathrm{~min}$, increase to $80^{\circ} \mathrm{C}$ at $25^{\circ} \mathrm{Cmin}^{-1}$, hold for $7 \mathrm{~min}$. All analyses were run in triplicate and mean values are reported. Reproducibility for triplicate analyses was $\pm 5 \%$. Analyses for $\delta^{13} \mathrm{C}$ values were performed by continuous flow compound-specific carbon isotope analysis with a Finnigan MAT 252 mass spectrometer interfaced with a Varian 3400 capillary GC. Hydrocarbons were separated by a Poraplot $Q^{\mathrm{R}}$ column $(25 \mathrm{~m} \times 0.32 \mathrm{~mm}$ i.d. $)$ with the following temperature program: initial temperature of $40^{\circ} \mathrm{C}$, hold for $1 \mathrm{~min}$, increase to $190^{\circ} \mathrm{C}$ at $5^{\circ} \mathrm{Cmin}^{-1}$, hold for $5 \mathrm{~min}$. Total error incorporating both accuracy and reproducibility is $\pm 0.5 \%$ with respect to V-PDB (Sherwood Lollar et al., 2007a). The $\delta^{2} \mathrm{H}$ analysis was performed on a continuous flow compoundspecific hydrogen isotope mass spectrometer that consists of an HP 6890 GC interfaced with a micropyrolysis furnace in line with a Finnigan MAT Delta $^{+}$-XL. Total error incorporating both accuracy and reproducibility is $\pm 5 \%$ with respect to V-SMOW (Ward et al., 2004).

\section{DNA extraction}

A DNA extraction protocol from Barrett et al. (2006) was used to extract DNA from $0.7 \mathrm{~g}$ of LH sediment. This extraction technique was not successful for extracting DNA from LH sediment collected in 2006. Therefore, a PowerMax DNA isolation kit (MO BIO Laboratories, Solana Beach, CA, USA) was used to extract DNA from $\sim 12 \mathrm{~g}$ of LH sediment according to the manufacturers' protocol. DNA was quantified using a NanoDrop ND-1000 spectrophotometer. Consistent archaeal amplicon signals were obtained using $5 \mu \mathrm{l}$ of 1:10 diluted DNA for PCR as described below.

\section{Whole-genome amplification}

Bacteria could not be detected from DNA extracts by standard PCR; therefore, environmental DNA from LH sediment was amplified using the Genomiphi kit according to manufacturer's instructions (GE Healthcare, Buckinghamshire, UK). All, tubes, pipettes, pipette tips, water and reaction buffers were UV treated for $30 \mathrm{~min}$ in a Class II Biological Safety Cabinet (Thermo Electro Corporation, Marletta, IL, USA). A total of $4 \mu \mathrm{l}$ DNA from a 1:10 dilution in sterile UV-treated water was used as template. Both positive and negative (non-template control (NTC)) controls were undertaken according to manufacturer's instructions. To control some of the reported whole-genome amplification (WGA) shortcomings, we optimized WGA within an NTC reaction to a length of time whereby background amplification was not detectable by agarose gel electrophoresis. Polymerase extension times greater than $2.5 \mathrm{~h}$ resulted in DNA amplification product in NTC. Therefore, a $2 \mathrm{~h}$ extension time was used for WGA, which provided no detectable DNA amplification in NTC reactions. This reaction was also used for as a negative control template for any subsequent PCRs, thus ensuring that bacterial signatures were not obtained from NTC WGA.

\section{Polymerase chain reaction}

Partial-length bacterial 16S rRNA genes were PCR amplified using primer pair 27F (5'-AGAGTTTGAT CCTGGCTCAG-3') and 758R (5'-CTACCAGGGTATC TAATCC-3') as described by Steven et al. (2007a). An extra negative control for bacterial PCR was also undertaken for the WGA consisting of a PCR using equal volume (as compared to the standard PCR) NTC WGA reaction as template. Archaeal PCRs were undertaken in $25 \mu \mathrm{l}$ reaction volumes containing $1 \times$ PCR buffer, $0.2 \mathrm{mM}$ of each dNTP, $3.5 \mathrm{mM} \mathrm{MgCl}_{2}$, $0.5 \mu \mathrm{M}$ of each primer $\left(109 \mathrm{~F}, 5^{\prime}\right.$-ACKGCTCAGTAA CACGT- $3^{\prime}$ and 934R, 5'-GTGCTCCCCCGCCAATTC CT-3') (Grosskopf et al., 1998), $6.25 \mu \mathrm{g}$ bovine serum albumin, $1 \mathrm{U}$ of Taq polymerase and $2 \mu \mathrm{l}$ of template DNA. Thermocycling conditions for archaeal PCR consisted of $94{ }^{\circ} \mathrm{C}$ for $5 \mathrm{~min}$ followed by 20 cycles of $94{ }^{\circ} \mathrm{C}$ for $30 \mathrm{~s}, 62{ }^{\circ} \mathrm{C}$ for $30 \mathrm{~s}$ decreasing $1{ }^{\circ} \mathrm{C}$ per cycle until $52{ }^{\circ} \mathrm{C}, 72{ }^{\circ} \mathrm{C}$ for $1 \mathrm{~min}$ and $30 \mathrm{~s}$. Then 15 cycles of $94{ }^{\circ} \mathrm{C}$ for $1 \mathrm{~min}, 52^{\circ} \mathrm{C}$ for $30 \mathrm{~s}, 72^{\circ} \mathrm{C}$ for $1 \mathrm{~min}$ and $30 \mathrm{~s}$ and a final extension of $5 \mathrm{~min}$ at $72^{\circ} \mathrm{C}$.

\section{Construction and analyses of $16 S$ rRNA gene clone libraries}

For each clone library, we combined and purified a total of three $16 \mathrm{~S}$ rRNA PCR products using a QIAquick PCR purification kit (Qiagen Sciences, Germantown, MD, USA). A 2:1 and 4:1 molar ratio of insert to vector was used for bacterial and archaeal clone libraries, respectively. Construction of 16S rRNA gene clone libraries using the pGEM-T Easy vector system (Promega, Madison, WI, USA) and clone screening using amplified ribosomal DNA restriction analyses (ARDRA) was performed as described previously (Steven et al., 2007a). Two representative clones from each operational taxonomic unit (based on ARDRA patterns) were sequenced verifying that similar ARDRA patterns 
did contain identical sequences. 16S rRNA sequences were manually edited and subjected to the CHIMERA_CHECK program of the Ribosomal Database Project (RDP II; Cole et al., 2003) and suspected chimeras checked using the Pintail program (Ashelford et al., 2005). Taxonomic affiliations were determined using the Classifier tool of the RDP II (Cole et al., 2007). Sequences were also compared to the GenBank database using the BLASTn algorithm (Altschul et al., 1990). The bacterial and archaeal sequences were deposited into the GenBank database as accession numbers GQ452781-GQ452795 and GQ452796GQ452803, respectively. Sequences of each clone library were aligned using ClustalW software and neighbor-joining phylogenetic trees were produced with MacVector 7.0 software package (Oxford Molecular Ltd., Oxford, UK) using Jukes-Cantor modeling with 1000 bootstrap re-samplings. Sampling coverage of the 16S rRNA gene clone libraries was estimated using the method by Good (1953), $(1-(n / N)) \times 100$, where $n$ is defined as the number of clones represented as a single ARDRA pattern and $N$ the total number of screened ARDRA patterns. Shannon diversity indices were calculated by the DOTUR software (Schloss and Handelsman, 2005).

\section{Microscopy}

Sediment and water collected from LH were stained with dichlorotriazinyl aminofluorescein and filtered onto a $0.22 \mu \mathrm{m}$ pore sized filter (Bloem, 1995). The LIVE/DEAD BacLight viability stain (Molecular Probes Inc., Invitrogen, Eugene, OR, USA) was used as per manufacturer's instructions and the sample filtered onto a $0.22 \mu \mathrm{m}$ pore sized filter and viewed as described below. CARD-FISH (catalyzed activated reporter deposition-fluorescent in situ hybridization) and counterstaining with DAPI (4',6-diamidino-2phenylindole) was undertaken as described by Pernthaler and Pernthaler (2007) and Pernthaler et al. (2001), using the probes EUB338 (Amann et al., 1990), ARCH915 (Stahl and Amann, 1991), ANME1350 (Boetius et al., 2000) and a negative control probe (NON338) (Wallner et al., 1993). All probes were constructed and purchased from Biomers, Ulm, Germany (www.biomers.net). All CARD-FISH analyses were undertaken as described previously (Pernthaler and Pernthaler, 2007). In short, $\sim 0.5 \mathrm{~g}$ of LH sediment was fixed and prepared for CARDFISH analyses in the field using a previously described formaldehyde-based method for sediment samples (Pernthaler et al., 2001) and transported to the laboratory at $<-5{ }^{\circ} \mathrm{C}$. The fixed sample was consequently filtered and attached onto polycarbonate filters $(0.22 \mu \mathrm{m}$ pore size $)$ and stored at $-20^{\circ} \mathrm{C}$ until further analyses (Pernthaler and Pernthaler, 2007). Cells attached to the filters were then permeabilized by lysozyme $\left(1 \mathrm{~h}\right.$ at $\left.37^{\circ} \mathrm{C}\right)$ and hybridization undertaken overnight at $35^{\circ} \mathrm{C}$ with formamide concentrations of $20 \%$ for NON338, $40 \%$ for ANME1-350 and 55\% for NON338, EUB338 and
ARCH915. Catalyzed reporter deposition (tyramide labeled with fluorochrome FAM) was undertaken for $15 \mathrm{~min}$ at $46^{\circ} \mathrm{C}$. Proteinase $\mathrm{K}$ digestion and ultrasonication of the original fixed sediment was also trialed; however, this did not influence CARDFISH cells counts (results not shown). Filters from all microscopy-based experiments were viewed using a fluorescent Nikon Eclipse E600 microscope (Nikon, Melville, NY, USA) with appropriate filter sets under a $\times 100$ objective. Duplicate sediment samples were analyzed for each sample year, with hybridized cells counted from 100 random fields. Counts are presented as averages from triplicate assays including standard deviations.

\section{Microbial isolation and identification}

Isolation and enrichment of microorganisms were undertaken from LH samples collected in both 2005 and 2006 field seasons. Media included: DSMZ (Deutsche Sammlung von Mikroorganisem und Zellculturen; www.dsmz.de) medium 97; (Halobacterium media); 371 (Natronobacterium media); 372 (Halobacterium media); modified medium 372 (modifications include $\left(\mathrm{l}^{-1}\right)$ : $1.5 \mathrm{~g}$ $\mathrm{Na}_{3}$-citrate $\cdot 2 \mathrm{H}_{2} \mathrm{O}, 0.015 \mathrm{~g} \mathrm{CaCl} 2 \cdot 2 \mathrm{H}_{2} \mathrm{O}, 1 \mathrm{ml}$ trace element solution SL-10, $10 \mathrm{ml}$ Balch's vitamin solution); medium 503 (targeting anaerobes including methanogens) tested with varied carbon sources $\left(2 \mathrm{gl}^{-1}\right)$ including xylan, yeast extract and glucose; yeast extract and trypticase peptone, acetate, trimethylamine and methanol and at both 10 and $20 \%$ $\mathrm{NaCl}$ concentrations; minimal salt medium $\left(0.1 \mathrm{~g} \mathrm{l}^{-1}\right.$ yeast extract, $0.1 \mathrm{gl}^{-1}$ cas-amino acids, $20 \% \mathrm{NaCl}$, pH 6.7); Difco R2A agar (Becton, Dickinson and Co., Mississauga, ON, Canada) supplemented with 10 and $20 \% \mathrm{NaCl}$; halophilic minimal medium as described by Rodriguez-Valera et al. (1980), HM medium as described by Ventosa et al. (1982), 'neutral' medium as suggested by Walsh D (personal communication); $\mathrm{l}^{-1} ; 5.1 \mathrm{~g}$ yeast extract, $1.02 \mathrm{~g}$ peptone, $1.02 \mathrm{~g}$ cas-amino acids, $160 \mathrm{~g} \mathrm{NaCl}, 20.0 \mathrm{~g}$ $\mathrm{MgCl}_{2} \cdot 6 \mathrm{H}_{2} \mathrm{O}, 23.3 \mathrm{~g} \mathrm{MgSO}_{4} \cdot 7 \mathrm{H}_{2} \mathrm{O}, 4.7 \mathrm{~g} \mathrm{KCl}, 13.3 \mathrm{ml}$ Tris-HCl (pH 7.5), $15 \mathrm{~g}$ agarose, $6 \mathrm{ml} 5 \mathrm{M} \mathrm{CaCl}_{2}$ ) supplemented with $100 \mu \mathrm{g} \mathrm{ml}^{-1}$ of penicillin-G, erythromycin and cycloheximide to target Archaea; 'alkaline' medium as suggested by Walsh $\mathrm{D}$ (personal communication); $\mathrm{l}^{-1}$; $1.0 \mathrm{~g} \quad \mathrm{KH}_{2} \mathrm{PO}_{4}, 1.0 \mathrm{~g}$ $\mathrm{KCl}, \quad 1.0 \mathrm{~g} \quad \mathrm{NH}_{4} \mathrm{Cl}, \quad 0.24 \mathrm{~g} \quad \mathrm{MgSO}_{4} \cdot 7 \mathrm{H}_{2} \mathrm{O}, \quad 0.17 \mathrm{~g}$ $\mathrm{CaSO}_{4} \cdot 2 \mathrm{H}_{2} \mathrm{O}, 1.0 \mathrm{ml} H$. volcanii trace elements (DSMZ) $5.0 \mathrm{~g}$ yeast extract, $5.0 \mathrm{~g}$ cas-amino acids, $15.0 \mathrm{~g}$ agarose $10 \mathrm{ml}$ of $4.7 \mathrm{M} \mathrm{Na}_{2} \mathrm{CO}_{3}, \mathrm{pH}$ 6.5) supplemented with $100 \mu \mathrm{g} \mathrm{ml}^{-1}$ of penicillin-G, erythromycin, cycloheximide to target archaea; medium used by Alain et al. (2006) including 10 and $20 \% \mathrm{NaCl}$ and headspace gases consisting of $\mathrm{CH}_{4}(100 \%), \mathrm{H}_{2} / \mathrm{CO}_{2}(80: 20 \%)$ and $\mathrm{N}_{2} / \mathrm{CO}_{2}(80: 20 \%)$ to enrich for microorganisms involved in sulfatedependent AOM. Partial 16S rRNA sequences were obtained from all isolates as described above and have been deposited in the NCBI database under 
the accession numbers GQ452804 to GQ452816. Maximum salt tolerances of the isolates were determined on isolation medium containing $\mathrm{NaCl}$ concentrations of 10, 15, 20 and $25 \% \mathrm{NaCl}$ and growth tested at temperatures of $-10,-5,5^{\circ} \mathrm{C}$ and room temperature. Identification of the isolates was undertaken using the RDP classifier algorithm (Cole et al., 2007).

\section{Results}

The LH site $\left(79.07678^{\circ} \mathrm{N} ; 90.21145^{\circ} \mathrm{W}\right)$ is characterized by a hollow cone-shaped salt tufa structure approximately $2 \mathrm{~m}$ high and $4 \mathrm{~m}$ in diameter (Figure 1a) formed by evaporative and freezing fractionation. During summer sampling expeditions $(2005,2006)$, the dome could be entered (Figure 1b) and contained dark sediment at the bottom overlaid by a shallow spring water layer. Gas was venting as bubbles through the sediment and spring water. During summer, discharge dissolves through the side of the $\mathrm{LH}$ tufa in a continuous stream, but during winter the outflow is blocked and water fills the interior of the tufa mound and overflows the side. During the winter sampling expeditions (2007, 2008), the salt dome (Figure 1c) was completely full with water (Figure 1d) with constant gas bubbling evident at the surface; however, due to the overlying water column, attempts to obtain sediment from LH were difficult and collected sediment consisted predominately of hydrohalite crystals. As a consequence, microbial-based analyses of the sediment for the winter expeditions $(2007,2008)$ were not undertaken due to the lack of sufficient quantities of sediment. The in situ parameters of LH sediment are listed in Table 1.
Chemical/physical analyses performed during late winter and summer expeditions occurring from 2005 to 2008 showed that LH is a stable environment with very stable temperatures, salinity, ORP, $\mathrm{H}_{2} \mathrm{~S}$ and dissolved oxygen concentrations. In summary, the LH sediment and overlying water is a perennial subzero $\left(-5^{\circ} \mathrm{C}\right)$, near-neutral, hypersaline (22-26\%), reducing $(\sim-165 \mathrm{mV})$, microaerophilic, oligotrophic environment. The sediment and overlying spring water (collected in 2005) is also rich in sulfate $\left(100000 \mathrm{mg} \mathrm{kg}^{-1} ; 1.04 \mathrm{M}\right)$ and $\left(5200 \mathrm{mgl}^{-1}\right.$; $0.054 \mathrm{M})$, respectively, with the major anions and cations concentrations $\left(\mathrm{mg} \mathrm{kg}^{-1}\right)$ within the sediment being as follows: 59000 calcium $(1.47 \mathrm{M})$, 13000 iron $(0.23 \mathrm{M}), 980$ magnesium $(0.04 \mathrm{M}), 450$ potassium $(0.01 \mathrm{M}), 55000$ sodium $(2.39 \mathrm{M}), 4200$ chloride $(0.11 \mathrm{M})$. Nitrite and nitrate were below detection limits (10 and $3 \mathrm{mg} \mathrm{kg}^{-1}$, respectively). Total carbon and organic carbon of the sediment was 0.48 and $0.45 \%$, respectively.

\section{Gas analyses}

The major gas discharging from the center of $\mathrm{LH}$ is methane $(\sim 50 \%)$ (Table 2a) with the $\mathrm{CH}_{4}$ isotopic composition being invariant regardless of the year or season sampled (Tables $2 \mathrm{~b}$ and $\mathrm{c}$ ). The low $\mathrm{CH}_{4} / \mathrm{C}_{2+}$ ratio and hydrogen and carbon isotope signatures (Tables $2 \mathrm{~b}$ and $\mathrm{c}$ ) are consistent with a thermogenic origin of the methane (Welhan, 1988; Whiticar, 1999). The very small discrimination in $\delta^{13} \mathrm{C}$ between dissolved inorganic carbon (DIC) and $\mathrm{CH}_{4}$, and between $\delta^{2} \mathrm{H}$ values for $\mathrm{CH}_{4}$ and spring $\mathrm{H}_{2} \mathrm{O}$ also indicate that hydrocarbon gases are not produced by microbial methanogenesis (Tables $2 \mathrm{~b}$ and c). The uniformity of both the gas composition
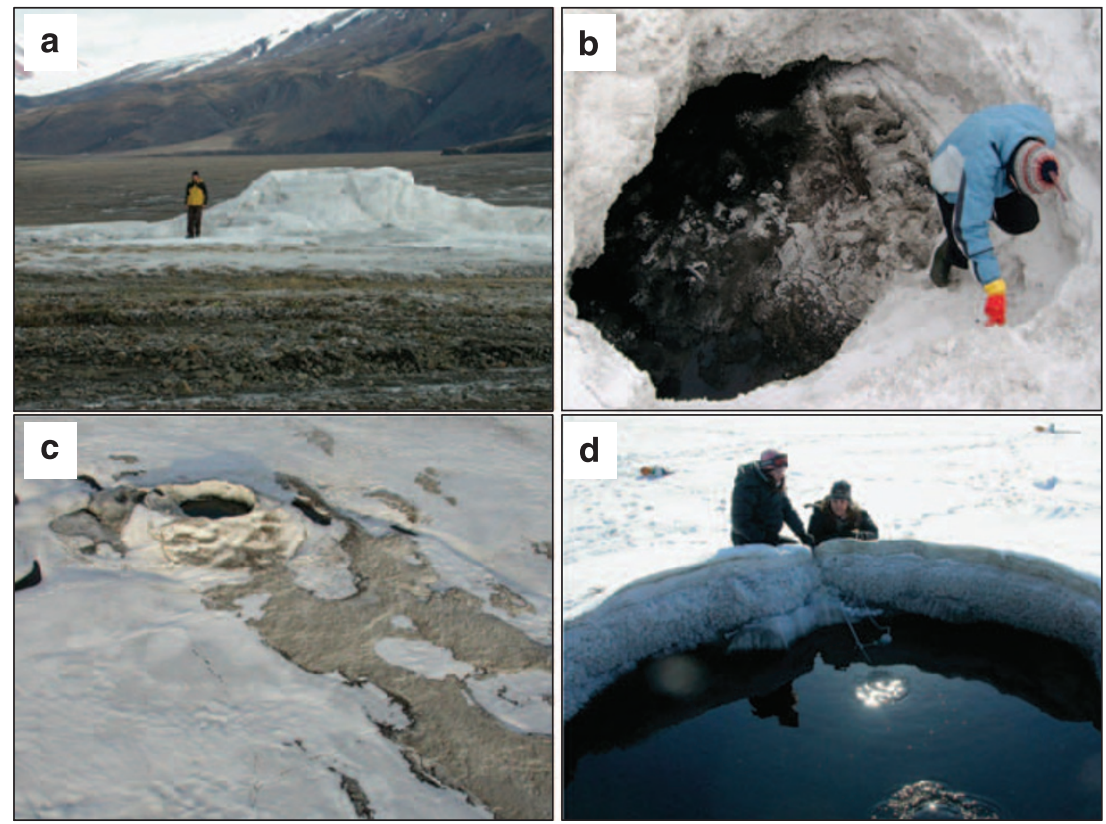

Figure 1 (a) View of Lost Hammer salt tufa during the summer; (b) Lost Hammer tufa empty of liquid during summer season; (c) Aerial view of Lost Hammer tufa and associated runoff during winter season; (d) Lost Hammer tufa full of liquid during winter season. 
Table 1 In situ geochemical parameters of Lost Hammer measured in July 2005 and 2006 (summer) and April 2007 and 2008 (late winter), including percentages of CARD-FISH cells of total DAPI-stained cells from 2005 and 2006 (counts unavailable for winter months due to difficulty in collecting sediment and consisted predominately of hydrohalite crystals)

\begin{tabular}{|c|c|c|c|c|}
\hline & 2005 & 2006 & 2007 & 2008 \\
\hline Temperature $\left({ }^{\circ} \mathrm{C}\right)$ & -4.8 & -4.9 & -4.7 & -5.9 \\
\hline $\mathrm{pH}$ & 6.3 & 5.96 & 6.37 & 7.38 \\
\hline DO (p.p.m.) ${ }^{\mathrm{a}}$ & 0.2 & 0.1 & ND & 1.0 \\
\hline $\mathrm{H}_{2} \mathrm{~S}$ (p.p.m.) ${ }^{\mathrm{a}}$ & $25-50$ & $0-20$ & $20-50$ & $20-30$ \\
\hline ORP $(\mathrm{mV})$ & -154.0 & -187.4 & -159.0 & -171.8 \\
\hline Conductivity $\left(\mu \mathrm{S} \mathrm{cm}^{-1}\right)$ & ND & $60761^{\mathrm{b}}$ & 116360 & 110992 \\
\hline TDS $\left(\mathrm{gl}^{-1}\right)$ & ND & $241.72^{\mathrm{b}}$ & 175.0 & 176.0 \\
\hline Salinity (\%) & $22-23$ & 26 & 22.4 & 22.1 \\
\hline Total cell count (DAPI) & $4.3 \pm 0.23 \times 10^{5}$ & $5.5 \pm 0.41 \times 10^{5}$ & ND & ND \\
\hline Bacterial cells (CARD-FISH) & $84.0 \% \pm 2.5$ & $79.2 \% \pm 2.6$ & ND & ND \\
\hline Archaeal cells (CARD-FISH) & $3.8 \% \pm 2.5$ & $2.5 \% \pm 1.1$ & ND & ND \\
\hline ANME-1 cells (CARD-FISH) & $3.4 \% \pm 0.5$ & $2.2 \% \pm 0.1$ & ND & ND \\
\hline
\end{tabular}

Abbreviations: DO, dissolved oxygen; ND, not determined; ORP, oxido-reduction potential; TDS, total dissolved solids.

aDetermined by CHEMetrics assay.

betermined using LH water diluted 1:4 in distilled water.

Table 2 (A-C) Analyses of gases venting in Lost Hammer

(a) Gas composition ( $\pm 5 \%$ )

\begin{tabular}{lcccccccrr}
\hline Collection year & $\mathrm{He}$ & $\mathrm{H}_{2}$ & $\mathrm{~N}_{2}$ & $\mathrm{CO}_{2}$ & $\mathrm{CH}_{4}$ & $\mathrm{C}_{2} \mathrm{H}_{6}$ & $C_{3} H_{8}$ & $i-C_{4} H_{10}$ & $n-C_{4} H_{10}$ \\
\hline 2005 & 0.14 & 0.81 & 28.4 & 13.5 & 56.0 & 1.09 & 0.09 & 0.02 \\
2006 & 0.07 & 0.64 & 39.3 & $\mathrm{NA}$ & 58.8 & 1.17 & 0.09 & 0.02 \\
2007 & 0.05 & 0.46 & 45.0 & 4.11 & 43.9 & 0.79 & 0.04 & 0.01 \\
2008 & 0.06 & 0.55 & 39.1 & 10.9 & 50.6 & 0.76 & 0.08 & 0.01 & 0.01 \\
& & & & & & & & 0.01 \\
\hline
\end{tabular}

(b) Hydrogen isotope (all results in \%o versus V-SMOW)

\begin{tabular}{|c|c|c|c|c|c|}
\hline Collection year & $\delta^{2} \mathrm{H}_{\mathrm{H}_{2}}$ & $\delta^{2} \mathrm{H}_{\mathrm{H}_{2} \mathrm{O}}$ & $\delta^{2} \mathrm{H}_{\mathrm{CH}_{4}}$ & $\delta^{2} \mathrm{H}_{\mathrm{C}_{2} \mathrm{H}_{6}}$ & $\delta^{2} \mathrm{H}_{\mathrm{C}_{3} \mathrm{H}_{8}}$ \\
\hline 2005 & b.d.l. & NA & -198 & -171 & b.d.l. \\
\hline 2006 & -820 & NA & -201 & -174 & -159 \\
\hline 2007 & -810 & -209 & -203 & -169 & -163 \\
\hline 2008 & NA & NA & NA & NA & NA \\
\hline
\end{tabular}

(c) Carbon isotope (all results in \%o versus V-PDB)

\begin{tabular}{lcccccc}
\hline Collection year & $\delta^{13} \mathrm{C}_{\mathrm{CO}_{2}}$ & $\delta^{13} \mathrm{C}_{\mathrm{CH}_{4}}$ & $\delta^{13} \mathrm{C}_{\mathrm{C}_{2} \mathrm{H}_{6}}$ & $\delta^{13} \mathrm{C}_{\mathrm{C}_{3} \mathrm{H}_{8}}$ & $\delta^{13} \mathrm{C}_{\mathrm{i}-\mathrm{C}_{4} \mathrm{H}_{10}}$ & $\delta^{13} \mathrm{C}_{\mathrm{n}-\mathrm{C}_{4} \mathrm{H}_{10}}$ \\
\hline 2005 & -26.2 & -38.3 & -28.0 & -24.8 & b.d.l. & $\delta^{13} \mathrm{C}_{\mathrm{DIC}}$ \\
2006 & -26.2 & -39.6 & -27.9 & -24.9 & -24.7 & b.d.l. \\
2007 & -25.9 & -38.0 & -27.8 & -24.3 & b.d.l. & NA \\
2008 & -26.2 & -38.3 & -27.6 & -24.7 & b.d.l. & b.d.l. \\
\hline
\end{tabular}

Abbreviations: DIC, dissolved inorganic carbon; b.d.l., below detection level; NA, not analyzed.

All results are corrected for air contamination after the method of Sherwood Lollar et al., 2007b.

and isotope signatures over the sampling years also suggests these are primary signatures and not related to secondary processes such as degradation or oxidation. Similarly, the relationship between the carbon isotope signatures for methane, ethane and propane supports a thermogenic origin based on the trend of increasing isotopic enrichment (less negative $\delta^{13} \mathrm{C}$ values) with increasing molecular weight. The very ${ }^{2} \mathrm{H}$-depleted isotopic signature of the $\mathrm{H}_{2}$ gas phase is typical of subsurface $\mathrm{H}_{2}$ but does not pinpoint its origin (Sherwood Lollar et al., 2007b).
Possible sources include degradation of organic matter as well as geologic sources.

\section{Microscopy}

CARD-FISH analyses of sediment collected in 2005 indicated that Bacteria accounted for $84.0 \%$ and Archaea $3.8 \%$ of total DAPI-stained cells $\left(4.3 \times 10^{5}\right.$ cells per g sediment). Live/Dead staining revealing $4.4 \times 10^{5}$ viable, 'live' cells per g of wet sediment (see Table 1 for 2005 and 2006 cell counts). Dead 
'red' cells could not be quantified due to background red autofluorescence. Similarly, detection of methanogenic archaea by UV exposure proved impossible due to background autofluorescence. CARD-FISH observations indicated that cells within LH sediment were typically associated with sediment particles. Total cell counts (DAPI staining) for sediment collected in 2006 did not vary significantly as compared to the 2005. Cell counts for the 2007 and 2008 samples could not be determined due to the presence of hydrohalite crystals. Anaerobic methane group 1 (ANME-1) cells (cylindrical, shortrod morphology) were also detected in LH sediment (see Table 1 for 2005 and 2006 results) accounting for approximately $2.2-3.4 \%$ of the total microbial cells and accounted for almost all the archaeal cells identified in LH sediment.

\section{Microbial molecular-based analyses}

Various difficulties were encountered when attempting to PCR amplify DNA extracted from LH sediment. DNA concentrations were both below detection level $\left(<5 \mathrm{ng}^{-1}\right)$ and exhibited PCR inhibition. However, archaeal 16S rRNA genes were consistently amplified from DNA extracts diluted 1:10 with sterile water. Bacteria were not detected either by denaturing gradient gel elecrophoresisPCR or by near full-length 16S rRNA gene PCR from DNA extracted from LH sediment collected in 2005 and 2006. The lack of bacterial detection was not due to PCR inhibition as LH DNA extracts spiked with both 20 and $100 \mathrm{ng}$ DNA from a Marinobacter sp. provided successful bacterial PCR amplicons. Although various PCR modifications were undertaken to detect bacterial 16S rRNA genes, bacterial signatures were detected only by PCR by the use of increased DNA template concentrations from WGA of LH DNA sediment extract. WGA has provided increased concentrations of DNA from molecularbased microbial ecological studies of samples with low biomass (Gonzalez et al., 2005).

A total of 66 archaeal 16S rRNA gene clones and 61 bacterial clones were screened by ARDRA, providing a total of 7 unique phylotypes recovered for the archaeal and 9 for the bacterial clone libraries. Good's coverage of 98.48 and $95.08 \%$ and Shannon diversity index values of 1.39 and 1.65 were obtained for the archaeal and bacterial clone libraries ( $5 \%$ sequence distance cutoff), respectively, indicating a notably low diversity of microbes within the LH sediments. DNA-based denaturing gradient gel elecrophoresis analyses of soil taken from outside the LH tufa indicated that the detectable fraction of the LH microbial community was unique to the spring sediment when compared to the surrounding soils.

Archaeal sequences were related to signatures from hypersaline deep-sea methane-seep sediments (Figure 2a), with the dominant phylotype (47\%) related to the ANME-1a clade of AOM archaea (Figure 3); intact ANME-1a cells were also confirmed in the LH sediments via ANME-1 specific CARD-FISH (Table 1) as described above. The closest relative of the ANME-1a phylotypes was archaeal clone TA1a6 (97-98\%, >661 bp) from
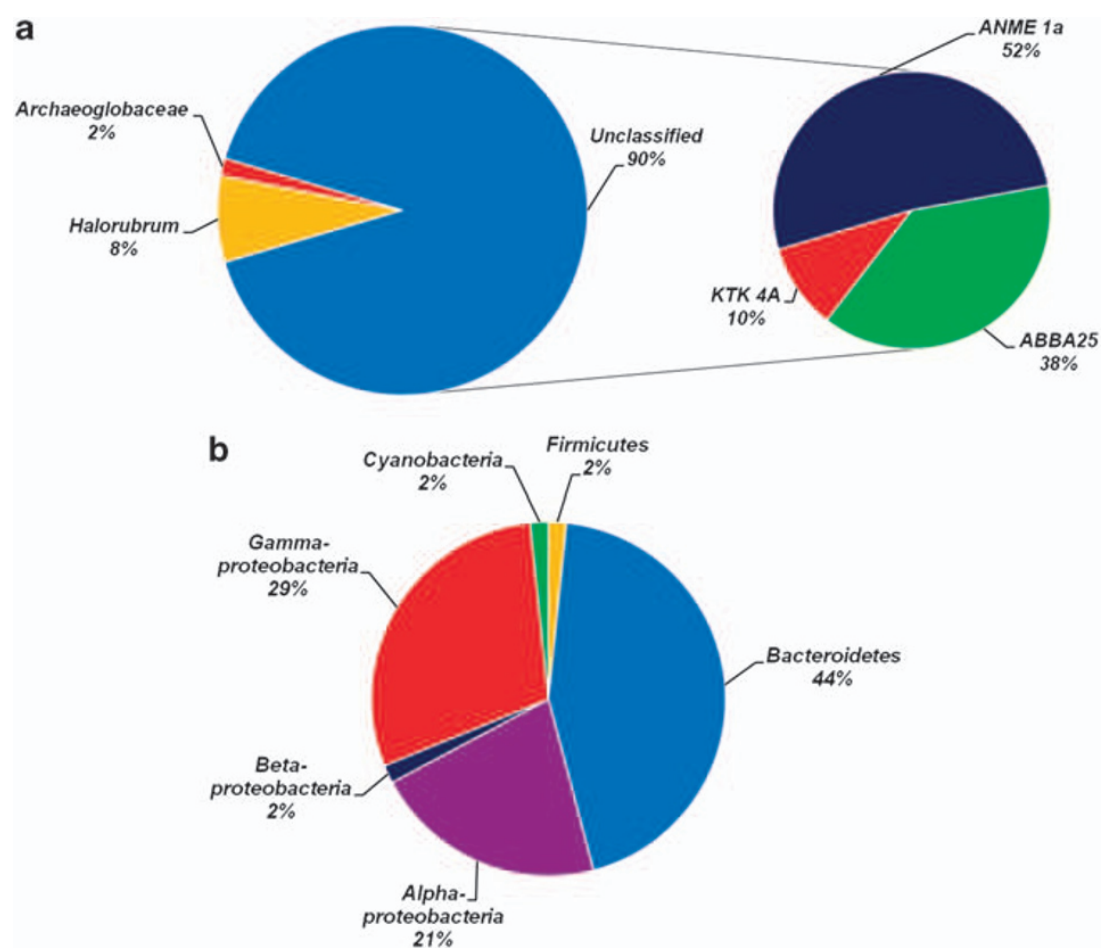

Figure 2 The composition of archaeal (a) and bacterial (b) 16S rRNA gene clone library phylotypes based on RDP classifier results. 


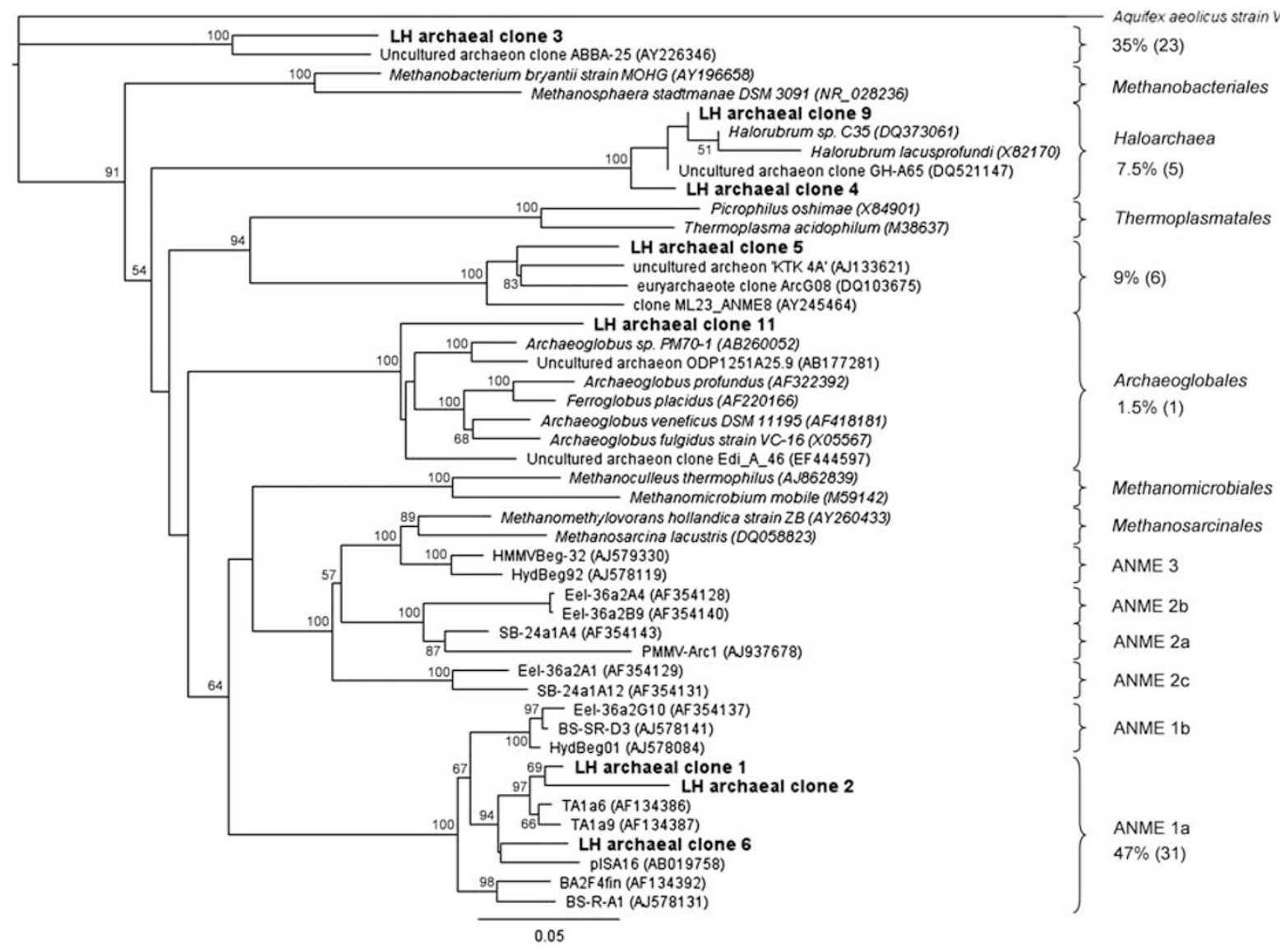

Figure 3 Phylogenetic relationships of archaeal 16S rRNA gene sequences recovered from Lost Hammer. Percentages indicate the prevalence of the clone types within the clone library with the number of clones indicated in parentheses. Bootstrap values $\geqslant 50 \%$ of 1000 replicates are indicated at the nodes. Bar, expected number of changes per nucleotide position.

marine methane-seep sediment (Hinrichs et al., 1999). Minor members of the archaeal 16S rRNA gene library included clones similar to clone ABBA-25 (91\%, $408 \mathrm{bp)}$ from a deep anoxic hypersaline basin (van der Wielen et al., 2005) and to an uncultured archaeon 'KTK 4A' (93\%, >728 bp) obtained from a highly saline sediment in the Red Sea (Eder et al., 1999). The remainder of the archaeal clones consisted of $8 \%$ of the sequences being very closely related (99\% over $792 \mathrm{bp}$ ) to the Halorubrum genus and 1 clone ( $2 \%$ of the total clone bank) grouping within the Archaeoglobaceae family with the closest NCBI BLAST relative being a sequence obtained from methane hydrate marine sediment (Inagaki et al., 2006).

Bacterial 16S rRNA gene signatures indicated a bacterial community (Figure 2b) dominated by members of the Bacteroidetes and also contained phylotypes such as Nostoc, Gillisia, Halomonas, Marinobacter and Loktanella (Figure 4) that were typically highly related to clones and/or isolates from terrestrial and marine environments of Antarctica and the Arctic, for example, Gillisia sp. (Van Trappen et al., 2004b; Bowman and Nichols, 2005; Nedashkovskaya et al., 2005), Halomonas and
Marinobacter spp. (Brinkmeyer et al., 2003) and Loktanella sp. (Van Trappen et al., 2004a).

\section{Microbial culture-based analyses}

A number of enrichments using media with a variety of modifications were undertaken in an attempt to obtain pure cultures from LH. Generally, few of the culturing attempts provided any signs of microbial growth following a 1-year incubation period. In total 13 isolates were obtained as listed in Table 3. All isolates were halotolerant bacteria $(10-20 \% \mathrm{NaCl})$ and all isolates capable of growth at both room temperature and $-5{ }^{\circ} \mathrm{C}$. All cultures were isolated on aerobic media with the exception of isolate 13 that was isolated under anaerobic conditions $\left(80 \% \mathrm{~N}_{2}\right.$ and $20 \% \mathrm{CO}_{2}$ ). For all isolates, the closest cultured relatives were also isolated from hypersaline and cold environments such as salt lakes, sediment of the Antarctic Ocean with isolates 1-4 and 5-6 most closely related to Bacillus and Halomonas spp., respectively, previously isolated from AHI GH spring indicating that similar cultivable communities within the springs of AHI. 16S rRNA gene sequence homologies between the Halomonas- and 
Aquifex aeolicus (AJ309733)

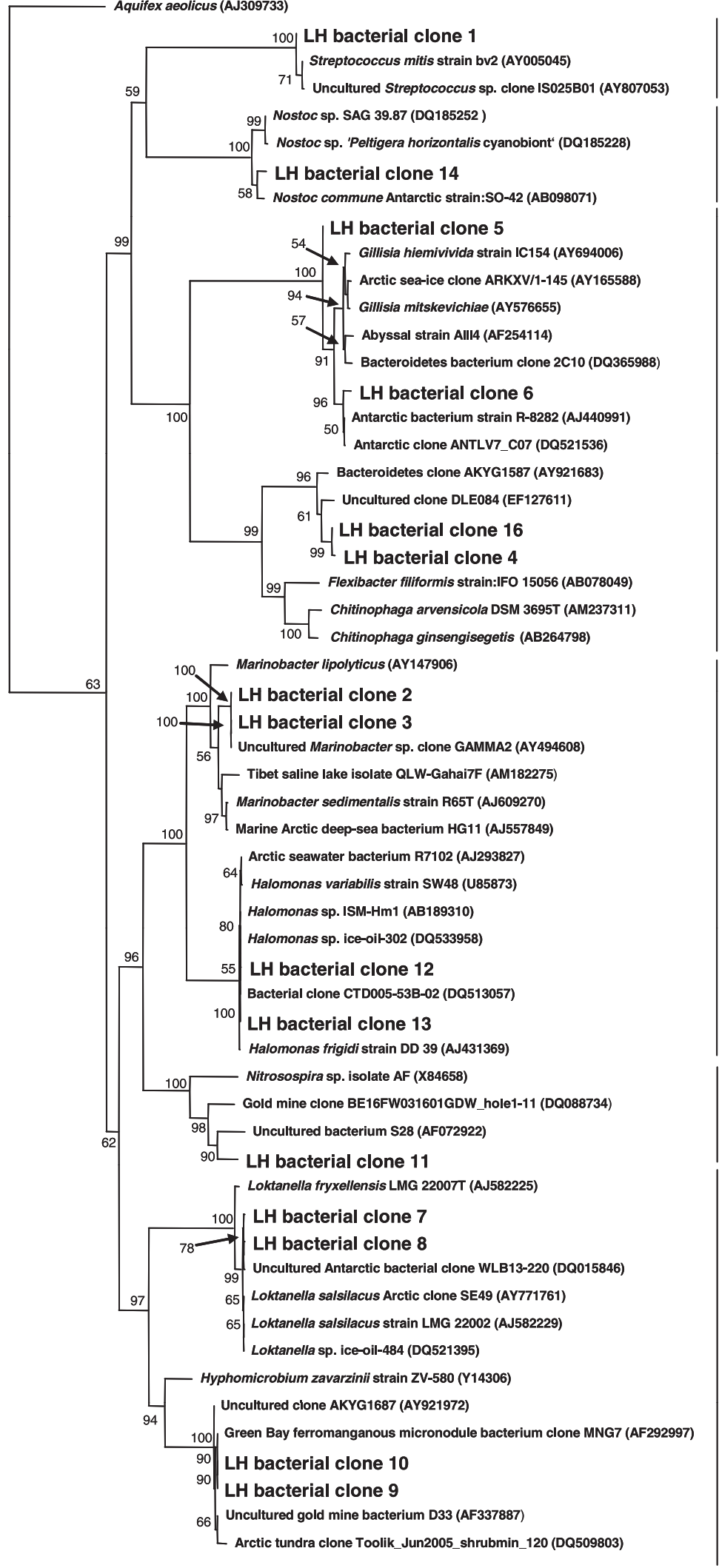

\section{Firmicutes}

$1.6 \%(1)$

Nostoc

$1.6 \%(1)$

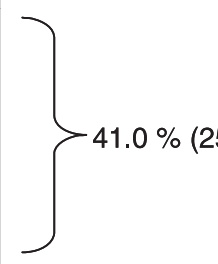

Bacteroidetes

\} $3.3 \%(2)$

\section{Gamma-Proteobacteria}<smiles>CCC(CC)CC</smiles>

\section{Beta-Proteobacteria}

$1.6 \%(1)$<smiles>CCC(CC)[Se][Ba]</smiles>

Alpha-Proteobacteria<smiles>CCC(CC)[15CH]CC[AsH3]</smiles>

Figure 4 Phylogenetic relationships of bacterial 16S rRNA gene sequences recovered from Lost Hammer. Percentages indicate the prevalence of the clone types within the clone library with the number of clones indicated in parentheses. Bootstrap values $\geqslant 50 \%$ of 1000 replicates are indicated at the nodes. Bar, expected number of changes per nucleotide position. 
Table 3 Identity of microorganisms isolated from LH and their respective low temperature and maximum salt tolerance limits of growth

\begin{tabular}{|c|c|c|c|c|c|c|c|}
\hline Isolate & $\begin{array}{l}\text { Isolation } \\
\text { medium }\end{array}$ & $\begin{array}{l}\text { Temperature } \\
\left({ }^{\circ} \mathrm{C}\right) \text { growth } \\
\text { range }\end{array}$ & $\begin{array}{l}\text { Max. } \mathrm{NaCl} \\
\text { tolerance }\end{array}$ & $\begin{array}{l}\text { Closest cultured } \\
\text { BLAST relative }\end{array}$ & $\begin{array}{l}\text { Origin of BLAST } \\
\text { relative }\end{array}$ & $\begin{array}{l}\text { Similarity } \\
\text { to BLAST } \\
\text { sequence }\end{array}$ & $\begin{array}{l}\text { RDP Classifier } \\
(\sim>80 \% \text { confidence })\end{array}$ \\
\hline $1-4$ & $\begin{array}{l}\text { DSMZ } 371 \\
\text { (aerobic) }\end{array}$ & -5 to $\mathrm{RT}^{*}$ & $20 \%$ & $\begin{array}{l}\text { Bacillus sp. NP16 } \\
\text { (EU196341) }\end{array}$ & $\begin{array}{l}\text { Axel Heiberg } \\
\text { Gypsum Hill } \\
\text { spring }\end{array}$ & $99 \%(408 / 409 \mathrm{bp})$ & $\begin{array}{l}\text { Sporolactobacillaceae } \\
\text { (family, } 100 \% \text { ) }\end{array}$ \\
\hline 5,6 & $\begin{array}{l}\text { DSMZ } 372 \\
\text { (aerobic) }\end{array}$ & -5 to $\mathrm{RT}^{*}$ & $20 \%$ & $\begin{array}{l}\text { Halomonas sp. } \\
\text { NP35 (EU196320) }\end{array}$ & $\begin{array}{l}\text { Axel Heiberg } \\
\text { Gypsum Hill } \\
\text { spring }\end{array}$ & 99\% (805/812 bp) & $\begin{array}{l}\text { Halomonas } \\
\text { (genus, } 100 \% \text { ) }\end{array}$ \\
\hline $7,8,9,12$ & $\begin{array}{l}\mathrm{R} 2 \mathrm{~A} \\
\text { (aerobic) }\end{array}$ & -5 to $\mathrm{RT}^{*}$ & $\begin{array}{l}10,20 \\
20,15 \%\end{array}$ & $\begin{array}{l}\text { Marinobacter sp. } \\
\text { ZS1-16 (FJ889664) }\end{array}$ & $\begin{array}{l}\text { Antarctic } \\
\text { Ocean marine } \\
\text { sediment }\end{array}$ & $100 \%(383 / 383 \mathrm{bp})$ & $\begin{array}{l}\text { Marinobacter } \\
\text { (genus, } 100 \% \text { ) }\end{array}$ \\
\hline 10,11 & $\begin{array}{l}\text { R2A } \\
\text { (aerobic) }\end{array}$ & -5 to $\mathrm{RT}^{*}$ & $10 \%$ & $\begin{array}{l}\text { Sediminibacillus } \\
\text { albus (DQ989634) }\end{array}$ & $\begin{array}{l}\text { Nanhobuxun } \\
\text { hypersaline salt } \\
\text { lake }\end{array}$ & $90 \%(153 / 169 \mathrm{bp})$ & $\begin{array}{l}\text { Bacillales } \\
\text { (order, } 100 \% \text { ) }\end{array}$ \\
\hline 13 & $\begin{array}{l}\text { DSMZ } 503 \\
\text { (anaerobic) } \\
(\text { glucose + } \\
\text { YE }^{A} \text { ) }\end{array}$ & -5 to $\mathrm{RT}^{*}$ & $10 \%$ & $\begin{array}{l}\text { Paraliobacillus } \\
\text { quinghaiensis } \\
\text { (EU135728) }\end{array}$ & $\begin{array}{l}\text { Haloalkaline salt } \\
\text { lake sediment }\end{array}$ & $97 \%(727 / 742$ bp $)$ & $\begin{array}{l}\text { Bacillaceae } \\
\text { (family, } 100 \% \text { ) }\end{array}$ \\
\hline
\end{tabular}

Abbreviations: $\mathrm{RT}^{*}$, room temperature $\left(\sim 22{ }^{\circ} \mathrm{C}\right)$; $\mathrm{YE}^{\boldsymbol{A}}$, yeast extract.

Marinobacter-related isolates and clones were not identical, suggesting that different species were represented in the clone libraries and culture collection. 16S rRNA gene sequence differences varied up to $\sim 2.4 \%$ (659 bp aligned sequence) and $6 \%$ (280 bp aligned sequence), respectively, for Halomonas and Marinobacter. Archaea were also targeted by the addition of antibiotics and cycloheximide (an eukaryotic protein synthesis inhibitor) to media; however, no archaeal isolates were obtained.

\section{Discussion}

The major gas exsolving from $\mathrm{LH}$ was methane $(\sim 50 \%)$ with the very small difference in $\delta^{13} \mathrm{C}$ values between $\mathrm{CO}_{2}$ and $\mathrm{CH}_{4}(12.1-13.4 \%$ ), indicating that the methane was not from microbial methanogenesis (Valentine, 2002) and also supported different origins for the thermogenic-derived hydrocarbons and the $\mathrm{CO}_{2}$ gas in these samples. The Strand Fiord geology includes several cycles of coal formation including outcrops in the vicinity of the LH spring, which provided a potential source of methane gas. Although not observed, the deep permafrost could contain coal bed gas in clathrate form (that is, methane hydrates). There was also no direct evidence of microbial methane utilization based on changes in $\delta^{13} \mathrm{C}_{\mathrm{CO}_{2}}$ or the $\delta^{13} \mathrm{C}_{\mathrm{CH}_{4}}$ signatures, although this is not unusual given the large $\mathrm{CH}_{4}$ and $\mathrm{CO}_{2}$ pools (50 and $>10 \%$ of the gas phase by volume). Attempts to identify methanotrophy in $\mathrm{LH}$ were made through changes in the $\delta^{13} \mathrm{C}_{\mathrm{CO}_{2}}$ or $\delta^{13} \mathrm{C}_{\mathrm{CH}_{4}}$ signatures; however, this approach is notoriously insensitive due to these mass balance issues and more recently developed approaches such as looking for ${ }^{13} \mathrm{C}$-depleted archaeal lipids coupled with molecular microbiological approaches have proven more successful (Orphan et al., 2002; Alain et al., 2006).

Sites characterized by high methane discharges and high salinities in cold temperature environments such as LH have not previously been described in terrestrial settings. Globally, such seeps are located at deep-sea marine sediments where methane hydrates occur (Valentine and Reeburgh, 2000; Valentine, 2002). Microbiological-based analyses of the LH sediment revealed a relatively low diversity (Shannon diversity index values of 1.65 and 1.39, respectively) of bacterial and archaeal $16 \mathrm{~S}$ rRNA phylotypes as compared with clone libraries from similar cryo-environments, including high Arctic permafrost (2.2-3.6 and 2.3-2.4; bacteria and archaea, respectively) (Steven et al., 2008), GH (3.17 and 2.12) and CP springs (2.16 and 2.77) of AHI (Perreault et al., 2007) and Antarctic soils (<3.32; bacteria) (Niederberger et al., 2008). Although the LH community appeared to be dominated by bacteria from CARD-FISH analyses, bacterial signatures were only detected by PCR in LH samples by the use of increased DNA template concentrations from WGA. The lack of PCR-based bacterial detection was not due to PCR inhibition as LH DNA extracts spiked with both 20 and $100 \mathrm{ng}$ of Marinobacter sp. DNA (isolate 7, Table 3) provided successful bacterial PCR products. Therefore, insufficient cell lysis or DNA recovery during the DNA extraction protocol may have led to these problems. Recovered bacterial phylotypes were related to organisms found in very cold and saline habitats, that is, Loktanella and Gillisia spp., isolated from microbial mats from Lake Fryxell, Antarctica (Van Trappen et al., 2004a, b) and microorganisms residing in Antarctic and Arctic Sea ice and water such as Gillisia (Bowman and Nichols, 
2005; Nedashkovskaya et al., 2005), Halomonas and Marinobacter (Brinkmeyer et al., 2003). Interestingly, we were able to culture a proportion of the bacterial phylotypes detected by the DNA-based methods including Marinobacter and Halomonas with all isolates capable of growth at the in situ temperature $\left(-5^{\circ} \mathrm{C}\right)$ of $\mathrm{LH}$ and 8 of 13 isolates capable of growth at the high in situ salinity concentrations $(20 \%)$. Although ANME-related microorganisms were not detected in the source pool sediment from other AHI springs, similarities do exist between the bacterial communities of LH to that of $\mathrm{CP}$ and $\mathrm{GH}$, including the detection and isolation of Gillisia, Loktanella, Marinobacter, Halomonas and Cytophaga spp. (Perreault et al., 2007, 2008).

The microbial communities of marine-based methane-seep sediments have been intensively studied due to the phenomenon of AOM undertaken by the ANME group of archaea, typically coupled with sulfate-reducing bacteria (SRB), in these environments (Hinrichs et al., 1999; Michaelis et al., 2002; Hallam et al., 2004; Knittel et al., 2005; Nauhaus et al., 2005; Lloyd et al., 2006). AOM is a globally important biological process as it influences the emission of this potential greenhouse gas into the hydrosphere (Knittel et al., 2005). Although the mechanisms of AOM metabolism are not fully understood, AOM is believed to occur through either reverse methanogenesis (Hallam et al., 2004; Caldwell et al., 2008), a type of acetogenesis (Valentine and Reeburgh, 2000; Caldwell et al., 2008) or methylogenesis (Caldwell et al., 2008; Moran et al., 2008). It has been shown that ANME cells (including ANME-1) form consortia with SRB cells to couple AOM with sulfate reduction (Valentine and Reeburgh, 2000; Orphan et al., 2002) and very recently it has been shown that AOM can also be coupled to denitrification (Raghoebarsing et al., 2006) or to the use of manganese and iron oxidants (Beal et al., 2009). Alternatively, it has also been theorized that ANME cells may undertake AOM autonomously (Orphan et al., 2002; Strous and Jetten, 2004) as some ANME cells have been observed alone. The ANME have thus far proven to be recalcitrant to cultivation and are classified into three putative taxonomic clades, ANME-1, -2 and -3 , based on $16 \mathrm{~S}$ rRNA gene phylogenies and are restricted to anoxic, methane-rich, sulfatecontaining sediments (Knittel et al., 2005).

Similar to observations of ANME-1 cells in other sites such as Lake Plußsee and deep marine methane-seep sites off the coast of Oregon and California (Orphan et al., 2002; Eller et al., 2005; Knittel et al., 2005), archaeal and ANME-1 cells within LH sediment were not closely associated to other cells as documented by complementing both CARD-FISH and DAPI microscopy. As previously hypothesized, these results may indicate that these cells undertake the entire AMO process, including sulfate reduction, that is, uncoupled to
SRB (Orphan et al., 2002; Strous and Jetten, 2004). Moreover, no signs of the putative AOM-associated syntrophic SRB group were detected in LH sediment, evidenced by the lack of both SRB-related phylotypes in the bacterial 16S rRNA gene library and the lack of observation of the typical ANME/ bacterial consortia morphologies by microscopic examination. However, Archaeoglobales-related signatures were obtained; Archaeoglobales are the only sulfate-reducing archaea known (Gaasterland, 1999). Therefore, these organisms may undertake AOM SRB-coupled activity in these environments, although inferences of metabolism determined by 16S rRNA gene phylogenies alone must be taken with some degree of caution. The presence of ANME cells in LH does not seem unlikely as optimal conditions for AOM metabolism exist within LH comprising of anoxic sediment with high concentrations of both sulfate and methane. There is only one report of ANME signatures in a terrestrial environment, a temperate $\left(12^{\circ} \mathrm{C}\right)$ Romanian mud volcano, although, unlike LH, ANME-2 were the dominant phylotype (Alain et al., 2006).

DNA is highly stable at high ionic concentrations, low temperatures and anoxic environmental conditions for extremely long periods of time (Inagaki et al., 2005). By analogy, LH may be a suitable environment for cryo-preservation of ancient DNA. Although this study has not proven that the $16 \mathrm{~S}$ rRNA genes recovered from LH are part of an in situ active microbial community per se, both LIVE/ DEAD and CARD-FISH microbial staining showed relatively high numbers of 'live' cells with the sediment of LH, that is, cells with intact cell membranes, and LH isolates were capable of growth at subzero temperatures and high salinities. We previously detected low heterotrophic microbial activities at subzero temperatures $\left(-5\right.$ and $\left.-10^{\circ} \mathrm{C}\right)$ within LH sediment (Steven et al., 2007b). However, it is difficult to discern if the archaeal phylotypes detected in LH are active or dormant under in situ conditions. Ongoing experiments including AOM activity assays using ${ }^{14} \mathrm{CH}_{4}$ are being undertaken to prove whether the ANME population is capable of oxidizing methane under ambient in situ conditions. Future work will also involve metagenomic analyses of the WGA DNA from LH sediment to investigate core metabolisms and provide insights of traits required for microbial life in this extreme hypersaline cryo-environment.

In conclusion, this multifaceted study characterized the microbial and geochemical components of LH and indicates that a viable microbial community may exist in this hypersaline, subzero environment. The LH site also provides an example of how a methane seep can form in thick extensive permafrost and provides a mechanism that could possibly be contributing to methane plumes on Mars (Mumma et al., 2009). The methane, regardless of origin, could behave as energy and carbon source for sustaining microbial life by AOM metabolism 
similar to the ANME-1 archaea that inhabit the very cold, salty LH sediments. Although methanogens have long been considered as prime candidates for possible microbial life on Mars, these results show how AOM microorganisms could also exist in analogous Martian environments.

\section{Acknowledgements}

Logistic support was provided by the Canadian Polar Continental Shelf Project (PCSP-08, 634-07, 664-06) and McGill University's High Arctic Research Station. This work was supported by grants from NASA's Exobiology program (NAG5-12395), the Natural Sciences and Engineering Research Council of Canada (NSERC) Discovery Program, Northern Supplements Program, Special Research Opportunities IPY Program and the Canadian Space Agency (CSA) Canadian Analogue Research Network program. Additional funding for student research was provided by the Department of Indian and Northern Affairs-Northern Scientific Training Program, and the Fonds Québécois de la Recherche sur la Nature et les Technologies (FQRNT). We also thank Buford Price for reviewing the article and suggestions for improvement before submission.

\section{References}

Alain K, Holler T, Musat F, Elvert M, Treude T, Krüger M. (2006). Microbiological investigation of methaneand hydrocarbon-discharging mud volcanoes in the Carpathian Mountains, Romania. Environ Microbiol 8: 574-590.

Allen CC, Oehler DZ. (2008). A case for ancient springs in Arabia Terra, Mars. Astrobiology 8: 1093-1112.

Altschul SF, Gish W, Miller W, Myers E, Lipman DJ. (1990). Basic local alignment search tool. J Mol Biol 215: $403-410$.

Amann RI, Krumholz L, Stahl DA. (1990). Fluorescentoligonucleotide probing of whole cells for determinative, phylogenetic, and environmental studies in microbiology. J Bacteriol 172: 762-770.

Andersen D, Pollard W, McKay C, Heldmann J. (2002). Cold springs in permafrost on Earth and Mars. J Geophys Res 107: 5015.

Ashelford KE, Chuzhanova NA, Fry JC, Jones AJ, Weightman AJ. (2005). At least 1 in 20 16S rRNA sequence records currently held in public repositories is estimated to contain substantial anomalies. Appl Environ Microbiol 71: 7724-7736.

Barrett JE, Virginia RA, Wall DH, Cary SC, Adams BJ, Hacker AL et al. (2006). Co-variation in soil biodiversity and biogeochemistry in northern and southern Victoria Land, Antarctica. Antarct Sci 18: 535-548.

Beal EJ, House CH, Orphan VJ. (2009). Manganese- and iron-dependent marine methane oxidation. Science 325: 184-187.

Bebout BM, Hoehler TM, Thamdrup B, Albert D, Carpenter SP, Hogan M et al. (2004). Methane production by microbial mats under low sulphate concentrations. Geobiology 2: 87-96.

Bloem J. (1995). Fluorescent staining of microbes for total direct counts. Molecular Microbial Ecology Manual. Kluwer Academic Publishers: Dordrecht, pp 1-12.
Boetius A, Ravenschlag K, Schubert CJ, Rickert D, Widdel F, Gieseke A et al. (2000). A marine microbial consortium apparently mediating anaerobic oxidation of methane. Nature 407: 623-626.

Bowman JP, Nichols DS. (2005). Novel members of the family Flavobacteriaceae from Antarctic maritime habitats including Subsaximicrobium wynnwilliamsii gen. nov., sp. nov., Subsaximicrobium saxinquilinus sp. nov., Subsaxibacter broadyi gen. nov., sp. nov., Lacinutrix copepodicola gen. nov., sp. nov., and novel species of the genera Bizionia, Gelidibacter and Gillisia. Int J Syst Evol Microbiol 55: 1471-1486.

Brinkmeyer R, Knittel K, Jurgens J, Weyland H, Amann R, Helmke E. (2003). Diversity and structure of bacterial communities in arctic versus Antarctic pack ice. Appl Environ Microbiol 69: 6610-6619.

Caldwell SL, Laidler JR, Brewer EA, Eberly JO, Sandborgh SC, Colwell FS. (2008). Anaerobic oxidation of methane: mechanisms, bioenergetics, and the ecology of associated microorganisms. Environ Sci Technol 42: 6791-6799.

Cole JR, Chai B, Farris RJ, Wang Q, Kulam-Syed-Mohideen AS, McGarrell DM et al. (2007). The ribosomal database project (RDP-II): introducing myRDP space and quality controlled public data. Nucleic Acids Res 35: D169-D172.

Cole JR, Chai B, Marsh TL, Farris RJ, Wang Q, Kulam SA et al. (2003). The ribosomal database project (RDP-II): previewing a new autoaligner that allows regular updates and the new prokaryotic taxonomy. Nucleic Acids Res 31: 442-443.

Conrad R, Frenzel P, Cohen Y. (1995). Methane emission from hypersaline microbial mats: lack of aerobic methane oxidation activity. FEMS Microbiol Ecol 16: 297-306.

Eder W, Ludwig W, Huber R. (1999). Novel 16S rRNA gene sequences retrieved from highly saline brine sediments of Kebrit Deep, Red Sea. Arch Microbiol 172: 213-218.

Eller G, Kanel L, Kruger M. (2005). Cooccurrence of aerobic and anaerobic methane oxidation in the water column of Lake Plußsee. Appl Environ Microbiol 71: 8925-8928.

Formisano V, Atreya S, Encrenaz T, Ignatiev N, Giuranna M. (2004). Detection of methane in the atmosphere of Mars. Science 306: 1758-1761.

Gaasterland T. (1999). Archaeal genomics. Curr Opin Microbiol 2: 542-547.

Gonzalez JM, Portillo MC, Saiz-Jimenez C. (2005). Multiple displacement amplification as a pre-polymerase chain reaction (pre-PCR) to process difficult to amplify samples and low copy number sequences from natural environments. Environ Microbiol 7: 1024-1028.

Good IL. (1953). The population frequencies of species and the estimation of population parameters. Biometrika 40: 237-264.

Grosskopf R, Janssen PH, Liesack W. (1998). Diversity and structure of the methanogenic community in anoxic rice paddy soil microcosms as examined by cultivation and direct 16S rRNA gene sequence retrieval. Appl Environ Microbiol 64: 960-969.

Hallam SJ, Putnam N, Preston CM, Detter JC, Rokhsar D, Richardson PM et al. (2004). Reverse methanogenesis: testing the hypothesis with environmental genomics. Science 305: 1457-1462.

Hinrichs K-U, Hayes JM, Sylva SP, Brewer PG, DeLong EF. (1999). Methane-consuming archaebacteria in marine sediments. Nature 398: 802-805. 
Inagaki F, Nunoura T, Nakagawa S, Teske A, Lever M, Lauer A et al. (2006). Biogeographical distribution and diversity of microbes in methane hydrate-bearing deep marine sediments on the Pacific Ocean margin. Proc Natl Acad Sci USA 103: 2815-2820.

Inagaki F, Okada H, Tsapin AI, Nealson KH. (2005). The paleome: a sedimentary genetic record of past microbial communities. Astrobiology 5: 141-153.

Joye SB, Boetius A, Orcutt BN, Montoya JP, Schulz HN, Erickson MJ et al. (2004). The anaerobic oxidation of methane and sulfate reduction in sediments from Gulf of Mexico cold seeps. Chem Geol 205: 219-238.

Knittel K, Losekann T, Boetius A, Kort R, Amann R. (2005). Diversity and distribution of methanotrophic archaea at cold seeps. Appl Environ Microbiol 71: $467-479$.

Lefèvre F, Forget F. (2009). Observed variations of methane on Mars unexplained by known atmospheric chemistry and physics. Nature 460: 720-723.

Lloyd KG, Lapham L, Teske A. (2006). An anaerobic methane-oxidizing community of anme-1b archaea in hypersaline Gulf of Mexico sediments. Appl Environ Microbiol 72: 7218-7230.

Malin MC, Edgett KS, Posiolova LV, McColley SM, Dobrea EZN. (2006). Present-day impact cratering rate and contemporary gully activity on Mars. Science 314: 1573-1577.

McLennan SM, Bell Iii JF, Calvin WM, Christensen PR, Clark BC, de Souza PA et al. (2005). Provenance and diagenesis of the evaporite-bearing burns formation, Meridiani Planum, Mars. Earth Planet Sci Lett 240: 95-121.

Michaelis W, Seifert R, Nauhaus K, Treude T, Thiel V, Blumenberg $\mathrm{M}$ et al. (2002). Microbial reefs in the Black Sea fueled by anaerobic oxidation of methane. Science 297: 1013-1015.

Moran JJ, Beal EJ, Vrentas JM, Orphan VJ, Freeman KH, House CH. (2008). Methyl sulfides as intermediates in the anaerobic oxidation of methane. Environ Microbiol 10: 162-173.

Mumma MJ, Villanueva GL, Novak RE, Hewagama T, Bonev BP, DiSanti MA et al. (2009). Strong release of methane on Mars in northern summer 2003. Science 323: 1041-1045.

Nauhaus K, Treude T, Boetius A, Krüger M. (2005). Environmental regulation of the anaerobic oxidation of methane: a comparison of ANME-I and ANME-II communities. Environ Microbiol 7: 98-106.

Nedashkovskaya OI, Kim SB, Lee KH, Mikhailov VV, Bae KS. (2005). Gillisia mitskevichiae sp. nov., a novel bacterium of the family Flavobacteriaceae, isolated from sea water. Int J Syst Evol Microbiol 55: 321-323.

Niederberger TD, McDonald IR, Hacker AL, Soo RM, Barrett JE, Wall DH et al. (2008). Microbial community composition in soils of Northern Victoria Land, Antarctica. Environ Microbiol 10: 1713-1724.

Niederberger TD, Perreault NN, Lawrence JR, Nadeau JL, Mielke RE, Greer CW et al. (2009). Novel sulfuroxidizing streamers thriving in perennial cold saline springs of the Canadian high Arctic. Environ Microbiol 11: $616-629$.

Orcutt B, Boetius A, Elvert M, Samarkin V, Joye SB. (2005). Molecular biogeochemistry of sulfate reduction, methanogenesis and the anaerobic oxidation of methane at Gulf of Mexico cold seeps. Geochim Cosmochim Acta 69: 4267-4281.

Oremland RS, Marsh L, Desmarais DJ. (1982). Methanogenesis in Big Soda Lake, Nevada: an alkaline, moderately hypersaline desert lake. Appl Environ Microbiol 43: 462-468.

Orphan VJ, House CH, Hinrichs KU, McKeegan KD, DeLong EF. (2002). Multiple archaeal groups mediate methane oxidation in anoxic cold seep sediments. Proc Natl Acad Sci USA 99: 7663-7668.

Osterloo MM, Hamilton VE, Bandfield JL, Glotch TD, Baldridge AM, Christensen PR et al. (2008). Chloridebearing materials in the southern highlands of Mars. Science 319: 1651-1654.

Pernthaler A, Pernthaler J. (2007). Fluoresence in situ hybridization for the identification of environmental microbes. In: Hilario E, MacKay JF (eds). Protocols for Nucleic Acid Analysis by Nonradioactive Probes 2nd edn. Humana Press: Totowa, NJ, pp 153-164.

Pernthaler J, Glöckner FO, Schönhuber W, Amann R. (2001). Fluorescence in situ hybridization. In: Paul J (ed). Methods in Microbiology: Marine Microbiology. Academic Press Ltd: London.

Perreault NN, Andersen DT, Pollard WH, Greer CW, Whyte LG. (2007). Characterization of the prokaryotic diversity in cold saline perennial springs of the Canadian high Arctic. Appl Environ Microbiol 73: 1532-1543.

Perreault NN, Greer CW, Andersen D, Tille S, LacrampeCouloume G, Sherwood Lollar B et al. (2008). Heterotrophic and autotrophic microbial populations in cold perennial springs of the High Arctic. Appl Environ Microbiol 74: 6898-6907.

Pollard W, Omelon C, Andersen D, McKay C. (1999). Perennial spring occurrence in the Expedition Fiord area of western Axel Heiberg Island, Canadian high Arctic. Can J Earth Sci 36: 105-120.

Potter EG, Bedout BM, Kelley CA. (2009). Isotopic composition of methane and inferred methanogenic substrates along a salinity gradient in a hypersaline microbial mat system. Astrobiology 9: 383-390.

Raghoebarsing AA, Pol A, van de Pas-Schoonen KT, Smolders AJP, Ettwig KF, Rijpstra WIC et al. (2006). A microbial consortium couples anaerobic methane oxidation to denitrification. Nature 440: 918-921.

Rivkina E, Shcherbakova V, Laurinavichius K, Petrovskaya L, Krivushin K, Kraev G et al. (2007). Biogeochemistry of methane and methanogenic archaea in permafrost. FEMS Microbiol Ecol 61: 1-15.

Rodriguez-Valera F, Ruiz-Berraquero F, Ramos-Cormenzana A. (1980). Behaviour of mixed populations of halophilic bacteria in continuous cultures. Can J Microbiol 26: 1259-1263.

Rohde RA, Price PB, Bay RC, Bramall NE. (2008). In situ microbial metabolism as a cause of gas anomalies in ice. Proc Natl Acad Sci USA 105: 8667-8672.

Rossi AP, Neukum G, Pondrelli M, van Gasselt S, Zegers T, Hauber E et al. (2008). Large-scale spring deposits on Mars? J Geophys Res 113: E08016.

Schloss PD, Handelsman J. (2005). Introducing DOTUR, a computer program for defining operational taxonomic units and estimating species richness. Appl Environ Microbiol 71: 1501-1506.

Sherwood Lollar B, Hirschorn SK, Chartrand MMG, Lacrampe-Couloume G. (2007a). An approach for assessing total instrumental uncertainty in compound-specific carbon isotope analysis: implications for environmental remediation studies. Anal Chem 79: 3469-3475.

Sherwood Lollar B, Voglesonger K, Lin L-H, LacrampeCouloume G, Telling J, Abrajano TA et al. (2007b). Hydrogeologic controls on episodic $\mathrm{H} 2$ release from 
Precambrian fractured rocks-energy for deep subsurface life on Earth and Mars. Astrobiology 7: 971-986.

Stahl DA, Amann RI. (1991). Development and application of nucleic acid probes. In: Stackebrandt E, Goodfellow M (eds). Nucleic Acid Techniques in Bacterial Systematics. Wiley: New York, pp 205-248.

Steven B, Briggs G, McKay CP, Pollard WH, Greer CW, Whyte LG. (2007a). Characterization of the microbial diversity in a permafrost sample from the Canadian High Arctic using culture-dependent and cultureindependent methods. FEMS Microbiol Ecol 59: 513-523.

Steven B, Niederberger TD, Bottos ER, Dyen MR, Whyte LG. (2007b). Development of a sensitive radiorespiration method for detecting microbial activity at subzero temperatures. J Microbiol Methods 71: 275-280.

Steven B, Pollard WH, Greer CW, Whyte LG. (2008). Microbial diversity and activity through a permafrost/ ground ice core profile from the Canadian High Arctic. Environ Microbiol 10: 3388-3403.

Strous M, Jetten MSM. (2004). Anaerobic oxidation of methane and ammonium. Annu Rev Microbiol 58: 99-117.

Tung HC, Bramall NE, Price PB. (2005). Microbial origin of excess methane in glacial ice and implications for life on Mars. Proc Natl Acad Sci USA 102: 18292-18296.

Valentine D. (2002). Biogeochemistry and microbial ecology of methane oxidation in anoxic environments: a review. Antonie Van Leeuwenhoek 81: 271-282.

Valentine DL, Reeburgh WS. (2000). New perspectives on anaerobic methane oxidation. Environ Microbiol 2: 477-484.

van der Wielen PWJJ, Bolhuis H, Borin S, Daffonchio D, Corselli C, Giuliano L et al. (2005). The enigma of prokaryotic life in deep hypersaline anoxic basins Science 307: 121-123.

Van Trappen S, Mergaert J, Swings J. (2004a). Loktanella salsilacus gen. nov., sp. nov., Loktanella fryxellensis sp. nov. and Loktanella vestfoldensis sp. nov., new members of the Rhodobacter group, isolated from microbial mats in Antarctic lakes. Int J Syst Evol Microbiol 54: 1263-1269.

Van Trappen S, Vandecandelaere I, Mergaert J, Swings J. (2004b). Gillisia limnaea gen. nov., sp. nov., a new member of the family Flavobacteriaceae isolated from a microbial mat in Lake Fryxell, Antarctica. Int J Syst Evol Microbiol 54: 445-448.

Ventosa A, Quesada E, Rodriguez-Valera F, Ruiz-Berraquero F, Ramos-Cormenzana A. (1982). Numerical taxonomy of moderately halophilic Gram-negative rods. J Gen Microbiol 128: 1959-1968.

Wallner G, Amann R, Beisker W. (1993). Optimizing fluorescent in situ hybridization with rRNA-targeted oligonucleotide probes for flow cytometric identification of microorganisms. Cytometry 14: 136-143.

Ward JA, Slater GF, Moser DP, Lin LH, LacrampeCouloume G, Bonin AS et al. (2004). Microbial hydrocarbon gases in the Witwatersrand Basin, South Africa: Implications for the deep biosphere. Geochim Cosmochim Acta 68: 3239-3250.

Welhan JA. (1988). Origins of methane in hydrothermal systems. Chem Geol 71: 183-198.

Whiticar MJ. (1999). Carbon and hydrogen isotope systematics of bacterial formation and oxidation of methane. Chem Geol 161: 291-314.

Zhang CL, Pancost RD, Sassen R, Qian Y, Macko SA. (2003). Archaeal lipid biomarkers and isotopic evidence of anaerobic methane oxidation associated with gas hydrates in the Gulf of Mexico. Org Geochem 34: 827-836. 